\title{
In vitro pollen viability of maize cultivars at different times of collection
}

\author{
Emanoel Sanches Martins ${ }^{1}$ Livia Maria Chamma Davide ${ }^{2 *}$ Gian José Miranda $^{2}$ \\ Jefferson de Oliveira Barizon ${ }^{2}$ Francisco de Assis Souza Junior ${ }^{2}$ \\ Rafael Pelloso de Carvalho ${ }^{3}$ Manoel Carlos Gonçalves ${ }^{2}$
}

${ }^{1}$ Departamento de Biologia, Universidade Federal de Lavras (UFLA), Lavras, MG, Brasil.

${ }^{2}$ Faculdade de Ciências Agrárias, Universidade Federal da Grande Dourados (UFGD), 79804-970, Dourados, MS, Brasil. E-mail: liviadavide@ufgd.edu.br. ${ }^{*}$ Corresponding author.

${ }^{3}$ Instituto Federal do Mato Grosso do Sul (IFMS), Ponta Porã, MS, Brasil.

ABSTRACT: In the present study, we aimed to assess the in vitro viability of pollen grains from maize cultivars collected at different times and days in the field. Four cultivars (Sol da Manhã, XB 6012, XB 8010, and BRS 2020) were evaluated from the second to fifth day of anthesis in three times. Pollen samples were evaluated for their in vitro viability through standard germination test in liquid and solid media and tetrazolium staining. The experimental design was completely randomized, in $4 x 4 x 3$ split-split plots with four replicates. Data were subjected to analysis of variance followed by a means clustering test and linear regression analysis. The average percentage of viable pollen varied according to the day, collection time, and cultivar. In general, XB 8010 and BRS 2020 had the highest frequency of viable pollen. The highest percentages of viable pollen were observed on the second day of anthesis at 10:00h.

Key words: anthesis, maize pollinization, Zea mays.

Viabilidade in vitro de pólen de cultivares de milho em diferentes tempos de coleta

RESUMO: O objetivo deste trabalho foi verificar a viabilidade in vitro de grãos de pólen de cultivares de milho em diferentes horários e dias no campo. Para tanto, foram coletados grãos de pólen de quatro cultivares (Sol da Manhã, XB 6012, XB 8010 e BRS 2020) do segundo ao quinto dia da antese em três horários diferentes. As amostras de pólen das cultivares foram avaliadas quanto à viabilidade in vitro por meio de teste de germinação em meio de cultura líquido e sólido e por teste de coloração em tetrazólio. O delineamento experimental utilizado foi inteiramente casualizado em parcelas subsubdivididas $4 \times 4 \times 3$ e quatro repetições. Dos dados obtidos a partir das análises de viabilidade polínica, fez-se a análise de variância, seguida de teste de agrupamento de média. As médias de viabilidade dos grãos de pólen de milho foram submetidas à análise de regressão linear. A porcentagem média de pólens viáveis variou de acordo com o dia, horário de coleta e cultivares de milho utilizadas. Em geral, os híbridos duplos apresentaram maior frequência de pólens viáveis. As maiores porcentagens de pólens viáveis foram observadas no segundo dia da antese e no horário das 10 horas da manhã.

Palavras-chave: antese, polinização, Zea mays.

\section{INTRODUCTION}

The in vitro study of maize pollen grains viability can provide relevant information on the best day and time of the day for pollen collection. Thus, it might help to improve the efficiency of plant breeding, and provide information on possible storage conditions that allow future pollen usage in the field.

Pollen viability is a well-known parameter for the assessment of plant male fertility. It is frequently used with stored pollen in order to ensure successful fertilization and enable breeding between economically valuable genotypes that blossom in different seasons (SOARES et al., 2011).
Pollen viability can be affected by several factors, such as handling of pollen during collection, tassel maturation stage, and external conditions like temperature and air humidity. According to ALMEIDA et al. (2002), recently formed pollen grains have higher viability than mature pollen. In addition, temperatures above $35^{\circ} \mathrm{C}$ and water stress can also have a negative impact on pollen production (MAGALHÃES \& DURÃES, 2006).

LUNA et al. (2001) observed that, within a temperature range of 28 to $30^{\circ} \mathrm{C}$ and relative humidity above $53 \%$, maize pollen remained viable for 2 hours. According to the authors, pollen viability decreased from 6 hours after anthesis, and 
only a very small percentage of pollen germinated after 1 to 3 days.

Several methods can be employed to assess pollen viability, such as the staining test with chemical dyes and in vitro and in vivo germination tests. The success of these methods depends on factors like the plant species and cultivar, plant nutritional status, season, time of the day, collection method, photoperiod, temperature, incubation period, and presence of micro and macronutrients in the culture medium (KAKANI et al., 2002; KAKANI et al., 2005; SOARES et al., 2008; CHAGAS et al., 2010; SINIMBÚ NETO et al., 2011). Several authors have used such methods to study pollen viability in maize (BARNABÁS et al., 1988; ALMEIDA et al., 2002; AYLOR, 2004, FERREIRA et al., 2007, DAVIDE et al., 2009).

In the present study, we aimed to assess the in vitro viability of pollen grains collected from different maize cultivars, at different days and time points.

\section{MATERIALS AND METHODS}

The experiment was carried out in the experimental field of the Faculdade de Ciências Agrárias of the Universidade Federal da Grande Dourados (UFGD), in Dourados city, Mato Grosso do Sul state, Brazil, at the approximate coordinates $22^{\circ} 13^{\prime} 15^{\prime} \mathrm{S}$ and $54^{\circ} 48^{\prime} 21^{\prime \prime} \mathrm{W}$, at $430 \mathrm{~m}$ altitude. Four maize cultivars with different agronomic traits were used: the variety Sol da Manhã, the simple hybrid XB 6012, and the double hybrids XB 8010 and BRS 2020. These genotypes were sowed thrice every seven days with no statistical design, to ensure the collection of the amount of pollen required for laboratory analyses. For each genotype, three lines $10 \mathrm{~m}$ in length were sowed with spacing of $0.9 \mathrm{~m}$ between lines and $0.25 \mathrm{~m}$ between plants. In each sowing, $400 \mathrm{~kg} \mathrm{ha}^{-1}$ of the $8(\mathrm{~N}): 28\left(\mathrm{P}_{2} \mathrm{O}_{5}\right): 16\left(\mathrm{~K}_{2} \mathrm{O}\right)$ formulation were used. The other cultivation practices were carried out following the usual recommendations for the maize crop.

During anthesis, temperature, relative humidity and precipitation were measured (Figure 1). Pollen grains from 10 plants of each genotype were collected from the second to the fifth day of anthesis, at three different times: $08: 00 \mathrm{~h}, 10: 00 \mathrm{~h}$ and 12:00h. For pollen collection, maize tassels were covered with impermeable Kraft paper and gently shaken to release the grains, after which samples were sifted to remove anthers. Then, $1.0 \mathrm{~mL}$ of pollen from each of the 10 plants of each cultivar was collected in $1.5 \mathrm{~mL}$ microtubes and immediately taken to the laboratory for the in vitro viability analysis.

Pollen viability was analyzed for the ability of grains to germinate in vitro in both liquid and solid culture media, and for tetrazolium stain ability. Both culture media were composed of $10 \%$ sucrose, $0.03 \%$ boric acid, and $0.15 \%$ calcium chloride, but the solid one was supplemented with $1.2 \%$ agar (FERREIRA et al., 2007, DAVIDE et al., 2009).

Germination of viable pollen in culture media was observed in an optical microscope under 10xmagnification. Four microscopic fields were observed, corresponding to four replicates. Pollen grains were considered germinated when the length of pollen tubes exceeded grain diameter.

For the analysis of pollen viability by the tetrazolium test, $5 \mathrm{~mL}$ of $0.75 \%$ 2,3,5-triphenyltetrazolium chloride were added to $0.05 \mathrm{~mL}$ of fresh pollen grains in a microtube, which was then covered with aluminium foil and placed in an BOD incubator at $25^{\circ} \mathrm{C}$ for $1 \mathrm{~h}$. After thein cubation period, pollen viability was analyzed by observing the staining of pollen mass in an optical microscope under a10x magnification. Four microscopic fields were observed, corresponding to four replicates. Pollen grains with a red staining were considered viable, whereas colorless pollen was considered unviable.

Experimental design of the laboratory analyses was completely randomized in subsubdivided plots, with 48 treatments and four replicates. Plots consisted of the four maize cultivars, while subplots consisted of the four days and three time points of pollen collection. The analyzedfeature was the in vitro viability of pollen grains.

Data were transformed to the arcsine $\sqrt{ } \%$ of viable pollen grains. Analysis of variance and Scott and Knott (1974) cluster analysis at $5 \%$ probability were performed using statistical software ASSISTAT 7.7 (SILVA, 2013). Means of the quantitative variables (percentage of viable pollen grains) were also subjected to linear regression analysis.

\section{RESULTS AND DISCUSSION}

Significant differences in the viability of maize pollen grains were detected among cultivars, days of anthesis, and times of day 
Table 1 - Analysis of the viability of maize pollen collected from four cultivars, in four days of anthesis and at three time points.

\begin{tabular}{lccc}
\hline Treatment $^{1}$ & Viability in liquid medium (\%) & Viability in solid medium (\%) & Viability in tetrazolium (\%) \\
\hline Cultivars (C) & $179.41^{* *}$ & $607.56^{* *}$ & $1293.81^{* *}$ \\
Sol da Manhã & $30.09 \mathrm{~b}$ & $21.74 \mathrm{~b}$ & $37.84 \mathrm{~b}$ \\
XB 6012 & $31.83 \mathrm{~b}$ & $24.03 \mathrm{~b}$ & $38.35 \mathrm{~b}$ \\
XB 8010 & $33.70 \mathrm{a}$ & $25.71 \mathrm{~b}$ & $45.21 \mathrm{a}$ \\
BRS 2020 & $34.36 \mathrm{a}$ & $30.16 \mathrm{a}$ & $48.38 \mathrm{a}$ \\
\hline Day (D) & $488.66^{* *}$ & $937.99^{* *}$ & $3533.36^{* *}$ \\
\hline 1 & $34.44 \mathrm{a}$ & $21.68 \mathrm{~b}$ & $31.88 \mathrm{c}$ \\
\hline 2 & $35.93 \mathrm{a}$ & $31.80 \mathrm{a}$ & $49.01 \mathrm{a}$ \\
\hline 3 & $30.33 \mathrm{~b}$ & $23.64 \mathrm{c}$ & $49.84 \mathrm{a}$ \\
4 & $29.28 \mathrm{~b}$ & $24.51 \mathrm{~b}$ & $39.04 \mathrm{~b}$ \\
Time (T) & $1774.58^{* *}$ & $1652.65^{* *}$ & $2334.54^{* *}$ \\
\hline $08: 00 \mathrm{~h}$ & $31.06 \mathrm{~b}$ & $26.43 \mathrm{~b}$ & $44.12 \mathrm{~b}$ \\
$10: 00 \mathrm{~h}$ & $38.33 \mathrm{a}$ & $29.90 \mathrm{a}$ & $47.47 \mathrm{a}$ \\
\hline $12: 00 \mathrm{~h}$ & $28.11 \mathrm{c}$ & $19.89 \mathrm{c}$ & $35.74 \mathrm{c}$ \\
C x D & $250.05^{* *}$ & $318.18^{* *}$ & $623.14^{* *}$ \\
C x T & $286.11^{* *}$ & $255.36^{* *}$ & $1077.39^{* *}$ \\
D x T & $312.62^{* *}$ & $409.64^{* *}$ & $1840.78^{* * *}$ \\
C x D x T & $488.52^{* *}$ & $201.85^{* *}$ & $578.85^{* *}$ \\
CV(\%) plot & 13.40 & 31.11 & 18.03 \\
CV(\%) subplot & 15.75 & 17.61 & 10.55 \\
CV(\%) sub-subplot & 15.72 & 17.71 & 12.24 \\
\hline
\end{tabular}

${ }^{1}$ Means followed by the same letters in a column do not differ by the Scott-Knott test at $5 \%$ probability. ${ }^{* *}$ Significant at $1 \%$ probability by the F test.

(Table 1). The double hybrids XB 8010 and BRS 2020 showed higher pollen viability than variety Sol da Manhã and the simple hybrid XB 6012 (Table 1). Pollen from XB 8010 and BRS 2020 showed viability values of $33.70 \%$ and $34.36 \%$, respectively, in liquid culture medium; $25.71 \%$ and $30.16 \%$, respectively, in solid culture medium; and $45.21 \%$ and $48.38 \%$, respectively, in the tetrazolium staining test.

The viability of pollen grains evaluated in liquid and solid culture media was similar to those reported in other studies (FERREIRA et al., 2007; DAVIDE et al., 2009). A relative humidity lower than $53 \%$, showing drastically reduced pollen grain viability (LUNA et al., 2001), which occurred in our study from the third day of pollen collection.

The time of day of pollen collection also influenced maize pollen viability. Pollen grains collected at 10:00h, when temperature and relative humidity were approximately $28.6^{\circ} \mathrm{C}$ and $56.25 \%$; respectively, were more viable than pollen collected at $08: 00 \mathrm{~h}$ and $12: 00 \mathrm{~h}$, when temperature ranged between 23.6 and $31.4^{\circ} \mathrm{C}$ and relative humidity ranged between $72.25 \%$ and
$42.5 \%$, respectively (data not shown). At 12:00h, mean pollen viability was the lowest. The most favorable climatic conditions for pollen viability probably occurred between 8:00 and 10:00h, when there was no excess of humidity in maize tassels and temperature was mild. These results are similar to those obtained by FERREIRA et al. (2007), who analyzed three different collection time points $(09: 00 \mathrm{~h}, 14: 00 \mathrm{~h}$, and $16: 00 \mathrm{~h})$ and observed the highest germination rate at $09: 00 \mathrm{~h}$ and the lowest at 16:00h.

High temperatures, usually observed from noon to late afternoon, can reduce the in vitro viability of pollen grains. KAKANI et al. (2005), for instance, reported that high temperatures during anthesis might lead to failure in pollination and/or fertilization, which results in reduced viability.

Regardless of the test used, the second day of pollen collection showed the highest percentage of pollen viability: $35.93 \%$ in liquid culture medium, $31.80 \%$ in solid culture medium, and $49.01 \%$ in the tetrazolium staining test (Table 1). These values indicated that the third day after the onset of anthesis is the best day to collect viable maize pollen. 


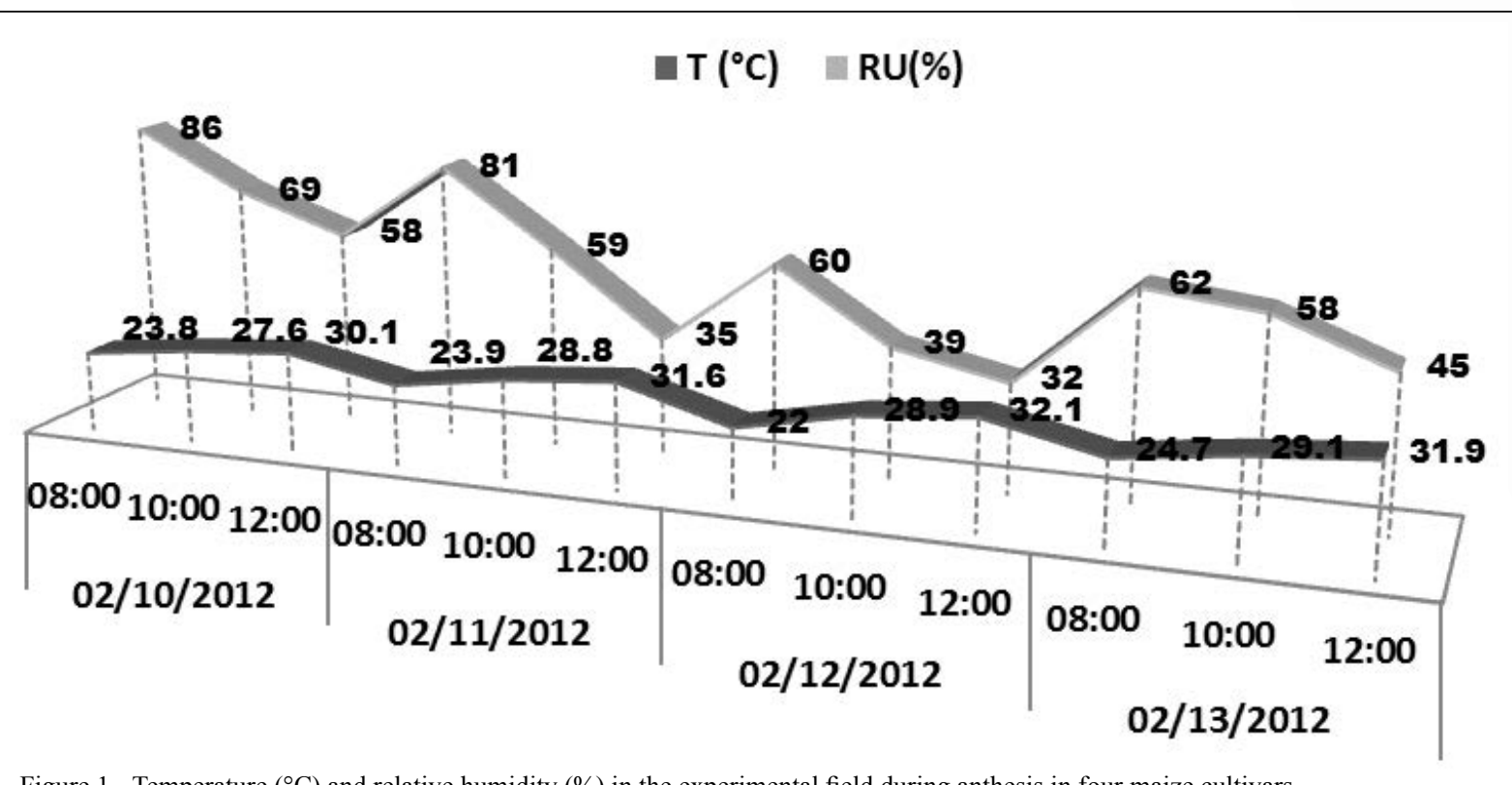

Figure 1 - Temperature $\left({ }^{\circ} \mathrm{C}\right)$ and relative humidity $(\%)$ in the experimental field during anthesis in four maize cultivars.

The viability of maize pollen grains was strongly influenced by the genotype and environmental conditions (Figures 1,2,3 and 4). The response of each cultivar to the different days and time points of collection can be observed in figures 2, 3, and 4. The genotype had a strong influence on the viability of maize pollen grains, but depending on the environmental conditions each cultivar showed different viability results.

When pollen was collected at 08:00h, XB 8010 and Sol da Manhã cultivars showed the best in vitro viability rates in solid culture medium (approximately 45\%), peaking in the second day of anthesis. The BRS 2020 cultivar showed values of approximately $40 \%$ in the first day, whereas XB 6012 showed a viability rate of $35 \%$ between the second and third days of anthesis (Figure 2). When cultured in liquid medium, pollen from XB 6012, XB 8010, and BRS 2020 showed the maximum values of viability, of approximately $45 \%$. This value was obtained between the first and second days of anthesis for XB 8010 and BRS 2020, and in the second day of anthesis for XB 6012. Pollen from Sol da Manhã; conversely, showed maximum values of approximately $40 \%$ between the first and second days of anthesis. In the tetrazolium staining test, pollen from BRS 2020 showed the highest viability, with values approaching $70 \%$ between the first and second days of anthesis, followed by XB 6012 and Sol da Manhã, with
$65 \%$ and $60 \%$ viability, respectively. In this test, pollen from XB 8010 showed the highest viability values in the first and second days of anthesis. The coefficients of determination $\left(\mathrm{R}^{2}\right)$ for most functions approached 1 , showing that the models we used were adequate to analyze the results from the cultivars.

Viability of pollen from BRS 2020 collected at 10:00h and cultured in solid medium was not significant and had a low coefficient of determination $\left(\mathrm{R}^{2}=0.21\right)$, suggesting that differences in pollen viability cannot be fully explained by the variations among the collection days (Figure 3). In contrast, pollen collected from the other cultivars had high coefficients of determination. XB 8010 showed the highest germination rates (approximately 40\%) between the third and fourth day of anthesis, while XB 6012 and Sol da Manhã showed $35 \%$ pollen viability in the second day. When cultured in liquid medium, pollen from Sol da Manhã had the highest rates among all cultivars, with viability values exceeding $55 \%$ at the second day of anthesis, followed by XB 8010 , with $50 \%$ on the third day. Pollen from XB 6012 had a low coefficient of determination $\left(\mathrm{R}^{2}=0.42\right)$, with little variation among the days of anthesis: $30 \%$ of viable pollen on the first day and approximately $40 \%$ on the fourth day.

Data on the tetrazolium test with pollen from all cultivars adequately fit their respective 


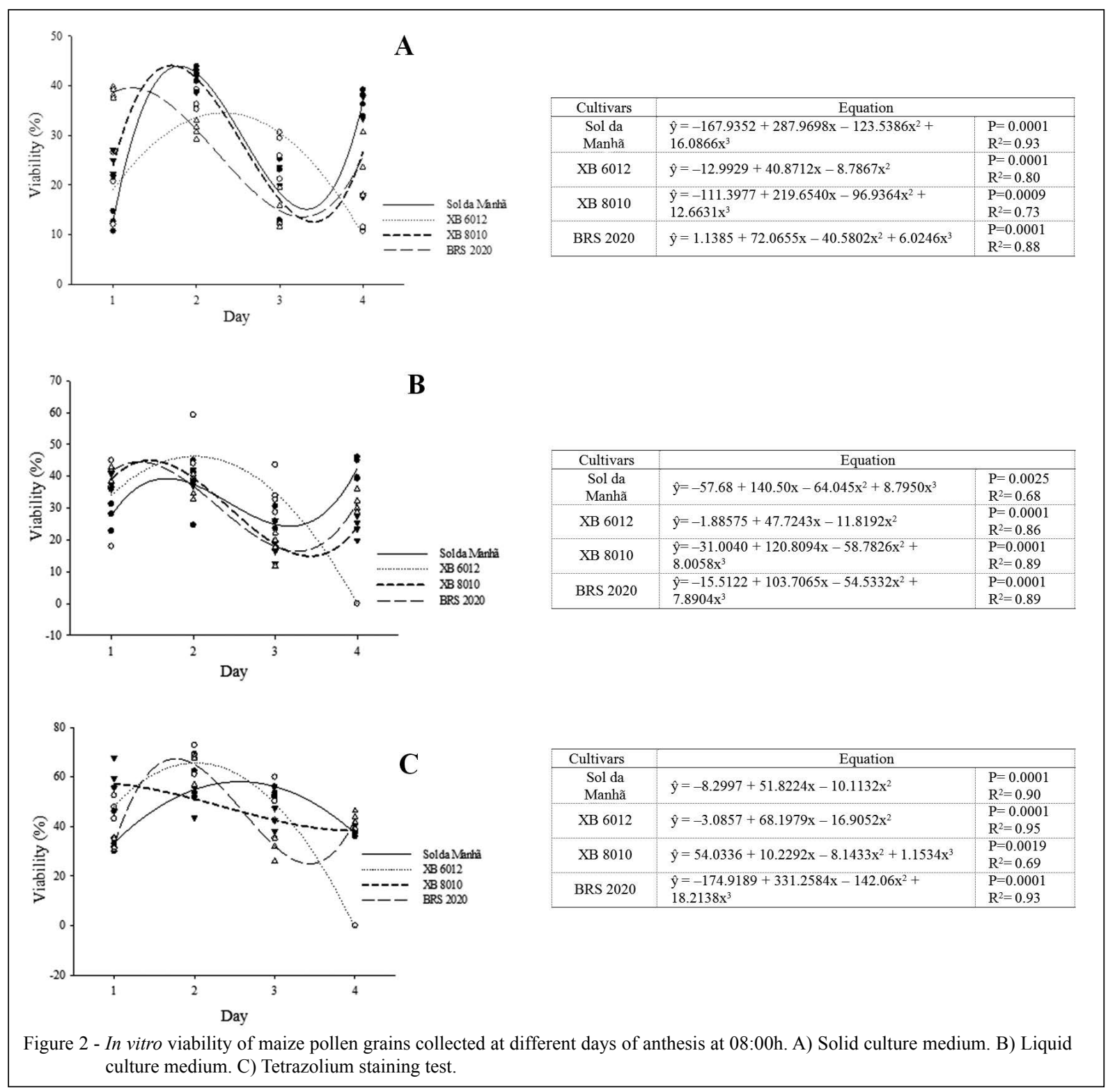

models. While Sol da Manhã and XB 8010 showed similar trends, with pollen viability peaking on the third day of collection with values above $60 \%$, BRS 2020 and XB 6012 showed $60 \%$ and $50 \%$ pollen viability; respectively, on the second day, with a decrease on the third day and a slight increase on the fourth.

Finally, at the last time point $(12: 00 \mathrm{~h})$, a low curve fitting was observed for pollen from Sol da Manhã cultured in solid medium $\left(\mathrm{R}^{2}=0.24\right)$ and for pollen from XB 6012 cultured in liquid medium $\left(\mathrm{R}^{2}=0.32\right)$, in both of which viability did not vary significantly across the days of anthesis (Figure 4). At 12:00h, the double hybrid BRS 2020 showed up to $15 \%$ higher pollen viability than the other cultivars, in both culture media and in the staining test. Notably, pollen from Sol da Manhã and XB 6012 collected at 12:00h. were less viable when compared to BRS 2020, showing that pollen collection at this time is not recommended for those two cultivars.

Sol da Manhã and XB 6012 showed higher viability for pollen collected at $08: 00 \mathrm{~h}$, when compared to the other time points, regardless of the culture medium. XB 8010, conversely, showed higher viability for pollen collected at 10:00h. It thus seems reasonable to suggest that differences in tassel morphology of the maize cultivars might 


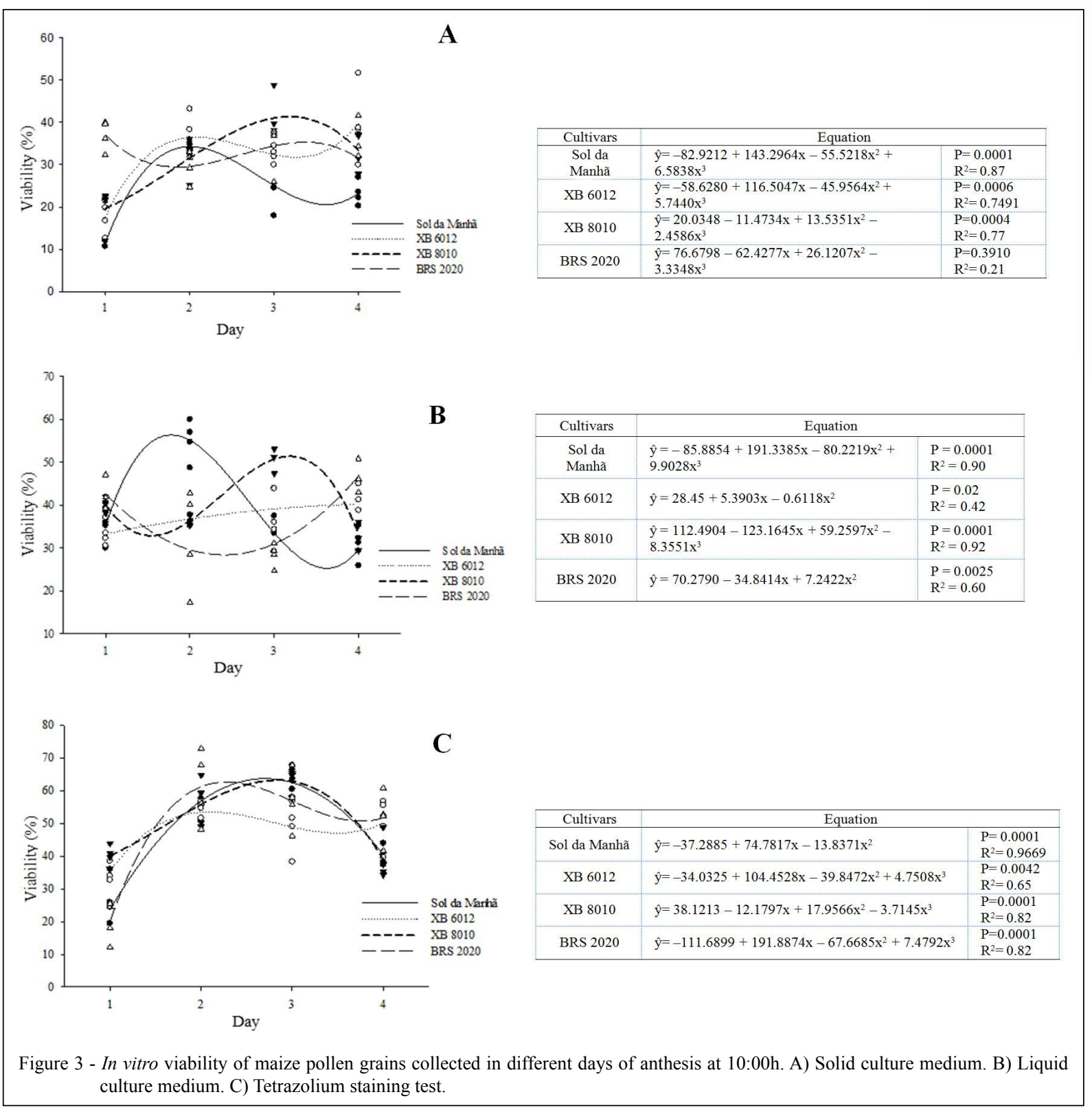

influence pollen grain viability. Thereby, tassels with higher angles of insertion between the rachis and lateral branches would have higher rates of pollen dehiscence since earlier in the day, as observed in Sol da Manhã and XB 6012 cultivars.

Our results corroborate those observed in previous studies on different crops, including maize (LUNA et al., 2001; ALMEIDA et al., 2002; BURKE et al., 2004; KAKANI et al., 2002; KAKANI et al., 2005; FERREIRA et al., 2007; DAVIDE et al., 2009; NOGUEIRA et al., 2010). Such studies reported differences in the in vitro pollen viability among cultivars, as well as the effects of temperature, relative humidity, and evaluation methods on the in vitro and in vivo pollen viability.

Although no statistical comparison was performed between the different viability tests, it was observed higher mean percentages of in vitro pollen viability in the tetrazolium staining test than in the culture in solid or liquid medium. Regardless, all tests used in our study provided relevant data to distinguish between different maize cultivars and identify the influence of different collection days and times on pollen viability. Our results supported 


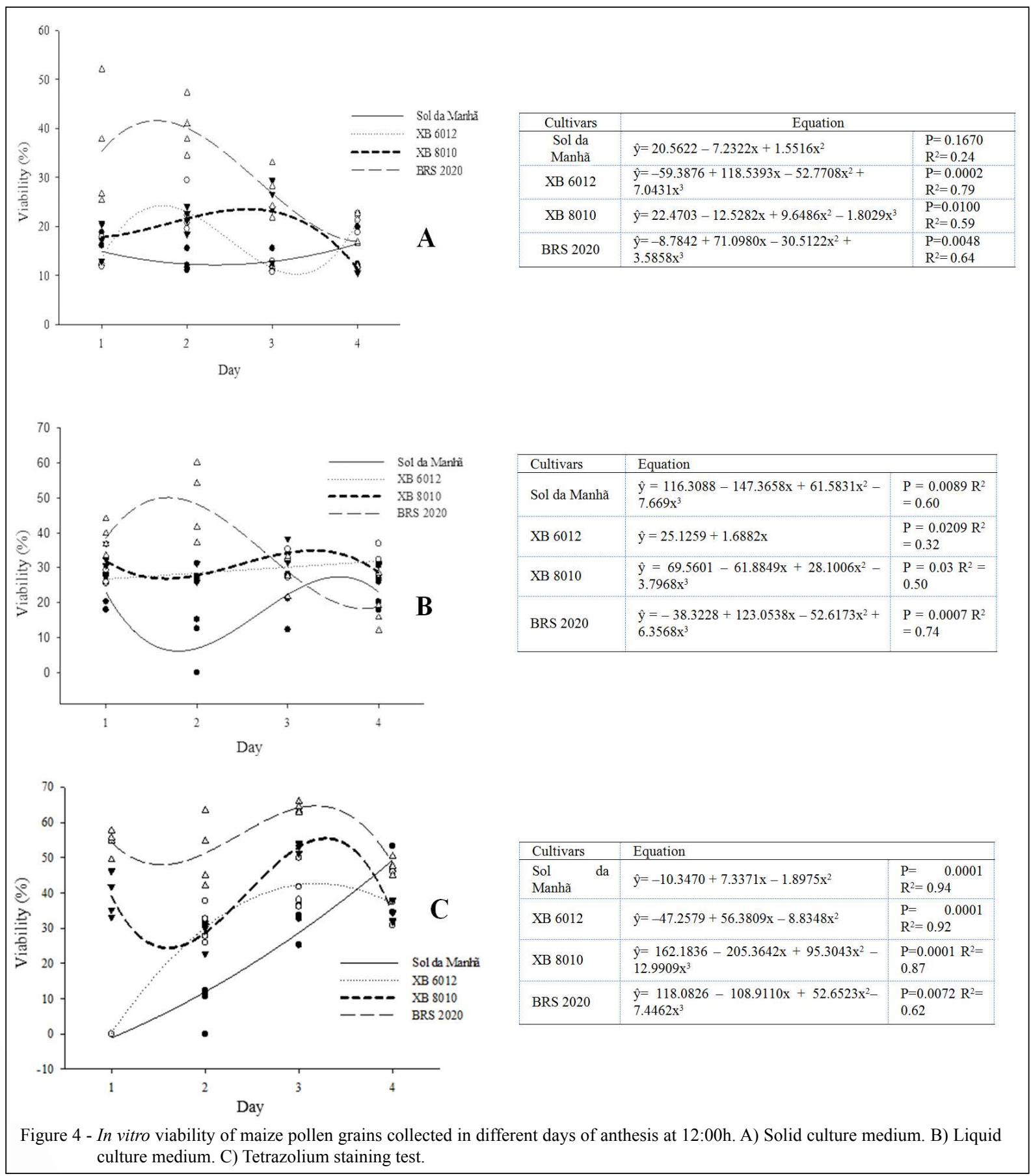

the importance of evaluating pollen viability in maize cultivars from which pollen is to be collected and stored for future use.

\section{CONCLUSION}

Between 08:00h and 10:00h of the third day of anthesis is the best period for collection of maize pollen, as it is when pollen grains have the highest viability.

\section{ACKNOWLEDGEMENTS}

We thank the Conselho Nacional de Desenvolvimento Científico e Tecnológico (CNPq) and the Universidade Federal da Grande Dourados (UFGD) for providing scientific initiation scholarship to the authors.

\section{REFERENCES}

ALMEIDA, C.C.S. et al. Efeito de desidratante e temperatura na estocagem de pólen de milho (Zea mays L.). In: CONGRESSO 
NACIONAL DE MILHO E SORGO, 24., 2002, Florianópolis, SC. Meio ambiente e a nova agenda para o agronegócio de milho e sorgo: resumos. Sete Lagoas: ABMS/Embrapa Milho e Sorgo/ EPAGRI, 2002. CD Room.

AYLOR D.E. Survival of maize (Zea mays) pollen exposed in the atmosphere. Agricultural and Forest Meteorology, v.123, p.125133, 2004. Available from: <http://www.sciencedirect.com/science/ article/pii/S0168192303003162>. Accessed: Apr. 10, 2015. doi: 10.1016/j.agrformet.2003.12.007.

BARNABÁS, B. et al. Effect of pollen storange by drying and deep freezing on the expression of different agronomic traits in maize (Zea mays L.). Euphytica, Wageningen, v.39, p.221-225, 1988. Available from: <http://link.springer.com/article/10.1007/BF00037099>. Accessed: Apr. 13, 2015. doi: 10.1007/BF00037099.

CHAGAS, E.A. et al. Medium composition and environmental conditions for the germination of pollen grains of pears rootsocks. Ciência Rural, v.40, n.2, p.231-236, 2010. Available from: <http:// dx.doi.org/10.1590/S0103-84782010000200002>. Accessed: May 10, 2014. doi: 10.1590/S0103-84782010000200002.

DAVIDE, L.M.C. et al. Viabilidade de pólen de milho em diferentes períodos de armazenamento em baixa temperatura. Revista Brasileira de Milho e Sorgo (Impresso), v.8, p.199-206, 2009.

FERREIRA, C.A. et al. Conservação e determinação da viabilidade de grão de pólen de milho. Revista Brasileira de Milho e Sorgo (Impresso), v.6, p.159-173, 2007. Available from: <http://dx.doi. org/10.18512/1980-6477/rbms.v6n2p159-17>. Accessed: Apr. 13, 2015. doi: $10.18512 / 1980-6477$.

KAKANI, V.G.et al. Response of in vitro pollen germination and pollen tube growth of groundnut (Arachis hypogaea L.) genotypes to temperature. Plant, Cell and Environment, v.25, p.1651-1661, 2002. Available from: <http://onlinelibrary.wiley.com/doi/10.1 046/j.1365-3040.2002.00943.x>. Accessed: May 12, 2015. doi: 10.1046/j.1365-3040.2002.00943.x.

KAKANI, V.G. et al. Differences in vitro pollen germination and pollen tube growth of cotton cultivars in response to high temperature. Annals of Botany, v.96, p.59-67, 2005. Available from: <http://www.ncbi.nlm.nih.gov/pmc/articles/PMC4246808/>. Accessed: May 12, 2015. doi: 10.1093/aob/mci149.

LUNA, V.S. et al. Maize pollen longevity and distance isolation requirements for effective pollen control. Crop Science, v.41, p.1551-1557, 2001. Available from: $\quad<$ https://dl.sciencesocieties.org/publications/cs/articles/41/5/1551>. Accessed: Feb. 12, 2015. doi: 10.2135/cropsci2001.4151551x.

MAGALHÃES, P.C.; DURÃES, F.O.M. Fisiologia do milho. Sete Lagoas: EMBRAPA-CNPMS, 2006. 10p. (Circular Técnica, 76).

NOGUEIRA, P.V. et al. Germinação de pólen e aplicação de ácido bórico em botões florais de nespereira. Bragantia, v.74, n.1, p.9-15, 2015. Available from: <http://www.scielo.br/pdf/brag/ v74n1/0006-8705-brag-74-1-9.pdf/>. Accessed: Feb. 12, 2015. doi: $10.1590 / 1678-4499.0264$.

SOARES, T.L. et al. In vitro germination and viability of pollen grains of banana diploids. Crop Breeding and Applied Biotechnology, v.8, p.111-118, 2008. Available from: <http://www.sbmp.org.br/ cbab/siscbab/uploads/bd6b9df0-14d5-c291.pdf > . Accessed: Apr. 12, 2015. doi: 10.12702/1984-7033.v08n02a03.

SOARES, T.L. et al. Morphology and viability of pollen grains from wild varieties of pineapple. Ciencia Rural, v.41, n.10, p.17441749, 2011. Available from: <http://www.scielo.br/pdf/cr/v41n10/ a12811cr5596.pdf $>$. Accessed: Apr. 28, 2015. doi: 10.1590/S010384782011001000011 .

SCOTT, A.; KNOTT, M. Cluster-analysis method for grouping means in analysis of variance. Biometrics, v.30, n.3, p.507-512, 1974. Available from: <http://www.jstor.org/stable/2529204>. Accessed: Feb. 02, 2015. doi: 10.2307/2529204.

SILVA, F. de A.S. The ASSISTAT Software: statistical assistance. 2013INPI 0004051-2. Available from: <http://www.assistat.com>. Accessed: May 12, 2014.

SINIMBÚ NETO, F.A. et al.Viabilidade in vitro de grãos de pólen de bacurizeiro - Clusiaceae. Revista Brasileira de Fruticultura, v.33, p.593-600, 2011. Available from: < http://www.scielo.br/pdf/rbf/v33n2/ AOP\%2004711.pdf>. Accessed: Nov. 13, 2014. doi: 10.1590/S010029452011005000062. 